\title{
PEMAHAMAN GURU DAN SISWA TENTANG MANAJEMEN BERBASIS SEKOLAH DI SMP NEGERI 8 PALANGKA RAYA
}

\author{
1Sundari, ${ }^{2}$ Setiawan \\ Program Studi Pendidikan Ekonomi, Fakultas Keguruan dan IImu Pendidikan \\ Universitas Palangka Raya, Palangka Raya, Kalimantan Tengah, Indonesia \\ e-mail: sundari29@fkip.upr.ac.id
}

\begin{abstract}
This study aims to determine the understanding of teachers and students about school-based management in the State Junior High School 8 Palangka Raya. The study involved 56 teachers and 248 students as research samples. The technique of collecting data in this study is by spreading the questionnaire, interviews, and documenting the necessary data. Based on the results of the data analysis that has been done, it can be concluded that teachers and students at State Junior High School 8 Palangka Raya has had an understanding of schoolbased management which is proven by the answer of the questionnaire. Teacher understanding is in good category with a percentage yield of $71.63 \%$ and student understanding is in category enough with a percentage yield of $59.87 \%$. In the future State Junior High School 8 Palangka Raya to make more efforts to improve the quality of teachers and students through workshops, trainings, and education seminars on school-based management, so that teachers and students better understand the understanding and implementation of school-based management, so that it is created a sense of having each other in school to improve the quality of education.
\end{abstract}

Keywords: Level of understanding, school-based management

\begin{abstract}
ABSTRAK
Penelitian ini bertujuan untuk mengetahui pemahaman guru dan siswa tentang manajemen berbasis sekolah di SMP Negeri 8 Palangka Raya. Penelitian ini melibatkan 56 guru dan 248 siswa sebagai sampel penelitian. Teknik pengumpulan data dalam penelitian ini adalah dengan menyebarkan angket/kuisioner, melakukan wawancara, dan mendokumentasikan data yang diperlukan. Berdasarkan hasil analisis data yang telah dilakukan, dapat disimpulkan bahwa guru dan siswa di SMP Negeri 8 Palangka Raya telah memiliki pemahaman tentang manajemen berbasis sekolah yang terbukti dengan hasil jawaban dari angket/kuisioner. Pemahaman guru berada dalam kategori Baik dengan hasil persentase $71,63 \%$ dan pemahaman siswa berada dalam kategori Cukup dengan hasil persentase $59.87 \%$. Kedepannya SMP Negeri 8 Palangka Raya agar lebih berupaya untuk meningkatkan kualitas guru dan siswa melalui workshop, pelatihan, diklat, maupun seminar pendidikan tentang manajemen berbasis sekolah, supaya guru dan siswa lebih memahami pengertian serta implementasi manajemen berbasis sekolah, sehingga tercipta rasa saling memiliki terhadap sekolah dalam meningkatkan mutu pendidikan yang berkualitas.
\end{abstract}

Kata Kunci: Tingkat Pemahaman, Manajemen Berbasis Sekolah

\section{PENDAHULUAN}

Dalam rangka memberikan respon terhadap tuntutan persaingan global saat ini, kita perlu terus mengembangkan dan meningkatkan kualitas sumber daya manusia (SDM) secara terencana, terarah, intensif, efektif, dan efisien dalam proses pembangunan. Wahana dan sarana yang paling strategis bagi peningkatan kualitas sumber daya manusia adalah pendidikan. 
Feiby Ismail (2018) menyatakan bahwa harkat dan martabat suatu bangsa sangat ditentukan oleh kualitas pendidikannya. Peningkatan kualitas pendidikan merupakan suatu proses yang terintegrasi dengan proses peningkatan kualitas sumber daya manusia. Peningkatan kualitas sumber daya manusia melalui pendidikan telah banyak dilakukan oleh Pemerintah dalam hal ini Kementerian Pendidikan dan Kebudayaan antara lain melalui pengembangan dan perbaikan kurikulum dan sistem evaluasi, perbaikan sarana pendidikan, pengembangan dan pengadaan materi ajar, pelatihan bagi guru dan tenaga kependidikan, serta pembinaan manajemen sekolah. Tetapi kenyataannya upaya tersebut belum cukup berarti dalam meningkatkan kualitas pendidikan.

Menurut Sallis (Husaini Usman, 2008) sebagian besar rendahnya mutu pendidikan disebabkan oleh buruknya manajemen dan kebijakan pendidikan. Warga sekolah hanyalah pelaksana dari kebijakan yang telah ditetapkan atasannya. MBS merupakan salah satu jawaban pemberian otonomi daerah di bidang pendidikan dan telah tercantum dalam UndangUndang Nomor 20 Tahun 2003 tentang Sistem Pendidikan Nasional Pasal 5 ayat (1) yang berbunyi, "Pengelolaan satuan pendidikan anak usia dini, pendidikan dasar, dan pendidikan menengah dilaksanakan berdasarkan standar pelayanan minimal dengan prinsip manajemen berbasis sekolah". Oleh karena itu, MBS wajib diketahui, dihayati, dan diamalkan oleh warga Negara Indonesia terutama mereka yang berkecimpung di dunia pendidikan anak usia dini, pendidikan dasar, dan pendidikan menengah.

MBS merupakan paradigma baru pendidikan yang memberikan otonomi luas pada tingkat sekolah dalam kerangka kebijakan pendidikan nasional. Otonomi diberikan agar sekolah leluasa mengelola sumber daya dan sumber dana dengan mengalokasikannya sesuai dengan prioritas kebutuhan serta lebih tanggap terhadap kebutuhan setempat (Murkan Sutarto dkk, 2012).

Dengan demikian sekolah secara mandiri tetapi masih dalam kerangka acuan kebijakan nasional dan ditunjang dengan penyediaan input yang memadai, memiliki tanggung jawab terhadap pengembangan sumber daya yang dimilikinya sesuai dengan kebutuhan belajar siswa dan masyarakat.

Kendatipun MBS telah diterapkan di sekolah, namun secara realita di lapangan belum sepenuhnya berjalan dengan baik. Penerapan konsep MBS di Indonesia masih menghadapi permasalahan yang cukup kompleks, terkait dengan kesiapan sumber daya pendidikan. Berdasarkan hasil kajian lapangan ditemukan berbagai permasalahan dalam implementasi MBS di sekolah, diantaranya yaitu (1) belum dipahaminya konsep MBS secara utuh dan benar oleh para pemangku kepentingan (stakeholders); (2) resistensi terhadap perubahan karena kepentingan, ketidakmampuan secara teknis dan manajerial, atau tertambat pada tradisi dan kelaziman yang telah mengkristal dalam tubuh sekolah dan dinas pendidikan; (3) kesulitan dalam menerapkan prinsip-prinsip MBS (kemandirian, kerjasama, partisipasi, keterbukaan, dan akuntabilitas); (4) belum optimalnya partisipasi pemangku kepentingan sekolah, dan (5) belum optimalnya teamwork yang kompak dalam menerapkan MBS (Depdiknas, 2009: 3132).

Tanggung jawab sekolah dalam Manajemen Berbasis Sekolah bukan hanya pada proses, tetapi tanggung jawab akhirnya adalah pada hasil yang dicapai. SMP Negeri 8 Palangka Raya sebagai institusi pendidikan berupaya untuk meningkatkan kualitas pendidikan sebagai wujud dari tanggung jawab sekolah dalam pelaksanaan manajemen berbasis sekolah dengan melakukan aktivitas sekolah yang paling utama yaitu mengadakan proses pendidikan dan pembentukan karakter baik mengadakan proses pembelajaran di dalam kelas maupun di luar kelas misalnya didukung dengan kegiatan ekstrakurikuler, penegakan disiplin dengan tata tertib, dan lain-lain. Kegiatan guru yang rutin dilakukan di SMP Negeri 8 Palangka Raya yaitu: (1) menguasai program pengajaran (garis-garis besar program); (2) menyusun program kegiatan mengajar; (3) menyusun model satuan pelajaran dan pembagian waktu; dan (4) melaksanakan tata usaha kelas, antara lain pencatatan data siswa. Sedangkan kegiatan yang dilakukan siswa di SMP Negeri 8 Palangka Raya yaitu: (1) berperan aktif dalam mengikuti proses belajar mengajar di sekolah; (2) berperan aktif 
mengikuti tata tertib dalam organisasi kesiswaan; serta (3) melaksanakan kegiatan yang telah diprogramkan oleh sekolah.

Aktivitas siswa dirancang dan disusun oleh pihak sekolah dalam hal ini guru-guru dengan berkoordinasi pada kepala sekolah dan staf administrasi disekolah. Kegiatan-kegiatan tersebut adalah:

1. Kegiatan Ekstrakurikuler.

Ada beragam kegiatan ekstrakurikuler di SMP Negeri 8 Palangka Raya, yang bertujuan untuk menyalurkan bakat dan minat siswa serta mendidik siswa untuk dapat bersosialisasi dengan lingkungan, memiliki jiwa kepemimpinan, mandiri, sportif, dan disiplin yang diharapkan dapat menunjang prestasi non akademik maupun akademik. Kegiatan-kegiatan ekstrakurikuler tersebut antara lain kepramukaan, Palang Merah Remaja (PMR), kegiatan olah raga seperti tenis meja, sanggar tari, drum band, dan olah raga (futsal, karate, basket, dan volly).

2. Kegiatan Intrakurikuler. Kegiatan intrakurikuler di SMP Negeri 8 Palangka Raya merupakan kegiatan siswa intra sekolah atau yang sering dikenal dengan sebutan OSIS. OSIS merupakan wadah bagi para siswa untuk berorganisasi dan belajar untuk bekerja sama, bersikap dewasa, mandiri, kreatif, dan inovatif.

Kegiatan-kegiatan yang dilakukan guru dan siswa seperti yang disebutkan sudah mencerminkan indikator pelaksanaan MBS, walaupun masih banyak permasalahan dan hambatan dalam pelaksanaannya. Permasalahan yang dihadapi adalah kurangnya dana untuk membantu kegiatan operasional sekolah, sarana dan prasarana pendidikan yang masih kurang memadai, serta kualitas sumber daya manusia (SDM) yang ada didalamnya.

Hambatan yang harus dibenahi terutama manajemen pengelolaan proses belajar mengajar guru dan kualifikasi guru yang belum menunjang sehingga mempengaruhi kualitas siswa. Guru mengajar tidak semata-mata berorientasi pada hasil (by product), tetapi juga berorientasi pada proses (by process) dengan harapan, makin tinggi proses makin tinggi pula hasil yang dicapai. Namun kenyataannya, suasana belajar mengajar yang terjadi di lapangan dalam lingkungan sekolah, siswa-siswa masih pasif dalam belajar. Usaha untuk menciptakan kondisi pembelajaran yang dapat melibatkan peran aktif siswa membutuhkan kemampuan guru dalam mengelola proses belajar mengajar sehingga siswa termotivasi untuk belajar yang pada akhirnya siswa mampu meningkatkan hasil belajar melalui pemahamannya.

Kekurangpahaman guru dan siswa mengenai MBS karena terkendala kurangnya dilakukan sosialisasi (pelatihan) mengenai materi manajemen berbasis sekolah yang dilakukan oleh pemerintah khususnya Dinas Pendidikan Provinsi/Kota kepada para guru dan siswa SMP Negeri 8 Palangka Raya.

Tujuan yang ingin dicapai dalam penelitian ini adalah untuk mengetahui pemahaman guru dan siswa tentang manajemen berbasis sekolah di SMP Negeri 8 Palangka Raya. Hasil penelitian ini diharapkan dapat bermanfaat untuk pengembangan ilmu pengetahuan khususnya di bidang pendidikan, yang mengacu pada pelaksanaan manajemen berbasis sekolah dan bermanfaat bagi mahasiswa Pendidikan Ekonomi yang akan melakukan penelitian terkait MBS.

\section{LANDASAN TEORI}

\section{Manajemen Berbasis Sekolah}

Manajemen berbasis sekolah diartikan sebagai model manajemen yang memberikan otonomi lebih besar kepada sekolah dan mendorong pengambilan keputusan partisipatif yang melibatkan secara langsung semua warga sekolah (guru, peserta didik, kepala sekolah, orang tua siswa, dan masyarakat yang berhubungan dengan program sekolah), sehingga rasa memiliki warga sekolah dapat meningkat yang mengakibatkan peningkatan rasa tanggung jawab dan dedikasi warga sekolah (Asmani, 2012).

Sekolah memiliki kewenangan (kemandirian) lebih besar dalam mengelola sekolahnya (menetapkan sasaran peningkatan mutu, menyusun rencana peningkatan mutu, melaksanakan rencana peningkatan mutu, dan melakukan evaluasi pelaksanaan peningkatan 
mutu) dan partisipasi-partisipasi kelompok-kelompok yang berkepentingan dengan sekolah merupakan ciri khas MBS.

\section{Tujuan Manajemen Berbasis Sekolah}

Tujuan adanya Manajemen Berbasis Sekolah menurut Prof. Dr. H. Djam'an Satori, MA (Asmani, 2012), adalah untuk meningkatkan mutu pendidikan dengan cara memberdayakan seluruh potensi sekolah dan stakeholder-nya sesuai dengan kebijakan pemerintah dengan menerapkan kaidah-kaidah manajemen pendidikan/sekolah professional.

Tujuan diadakannya manajemen berbasis sekolah atau manajemen pendidikan yaitu mengoptimalkan kinerja setiap substansi untuk mencapai tujuan pendidikan yang sudah ditentukan (Teguh Triwiyanto, 2015)

\section{Manfaat Manajemen Berbasis Sekolah}

Asmani (2012) menyatakan bahwa manfaat Manajemen Berbasis Sekolah (MBS) akan menghasilkan nilai positif bagi sekolah, yaitu:

a. Sekolah lebih mengetahui kekuatan, kelemahan, peluang, dan ancaman bagi sekolah yang bersangkutan sehingga sekolah dapat lebih mengoptimalkan pemanfaatan sumber daya yang ada.

b. Sekolah lebih mengetahui kebutuhan skala prioritas.

c. Pengambilan keputusan lebih partisipatif terutama dalam hal:

1) Menetapkan sasaran peningkatan mutu,

2) Menyusun rencana peningkatan mutu,

3) Melaksanakan rencana peningkatan mutu,

4) Melakukan evaluasi pelaksanaan peningkatan mutu.

d. Penggunaan dana lebih efektif dan efisien sesuai dengan skala prioritasnya.

e. Keputusan bersama lebih menciptakan transparansi dan demokrasi.

f. Dapat lebih meningkatkan rasa tanggung jawab.

g. Menumbuhkan persaingan sehat sehingga diharapkan adanya upaya inovatif.

Dengan demikian, Manajemen Berbasis Sekolah (MBS) memberikan kebebasan dan kewenangan yang luas kepada sekolah disertai seperangkat tanggung jawab serta mendorong profesionalisme guru dan terutama kepala sekolah sebagai pemimpin pendidikan yang ada di garda depan.

Manfaat yang diperoleh guru dengan adanya MBS adalah memungkinkan orang-orang yang kompeten di sekolah untuk mengambil keputusan yang akan meningkatkan pembelajaran; memberi peluang bagi seluruh guru untuk terlibat dalam pengambilan keputusan penting; meningkatkan motivasi guru dan mengembangkan jiwa kepemimpinan; serta guru memiliki kematangan sosial maupun emosional dalam berinteraksi dengan siswa dan anggota sekolah lainnya. Sedangkan manfaat yang diperoleh siswa dengan adanya MBS adalah diperolehnya siswa yang siap belajar dan dibuat beberapa rencana strategis dan operasional tentang kesiswaan untuk pembelajarannya, serta untuk pengembangan aspek keagamaan, kesehatan, kesenian, dan hubungan sosialnya (Asmani, 2012).

\section{Karakteristik Manajemen Berbasis Sekolah}

Saud (Mulyasa, 2007) mengemukakan bahwa karakteristik dasar MBS adalah pemberian otonomi yang luas kepada sekolah, partisipasi masyarakat dan orang tua peserta didik yang tinggi, kepemimpinan sekolah yang demokratis dan profesional, serta adanya team work yang tinggi dan profesional. Diharapkan sekolah yang memperhatikan dan memiliki karakteristik MBS mampu menerapkan MBS dengan sukses (H.M.Jufri Dolong, 2018).

\section{Implementasi Manajemen Berbasis Sekolah}

Implementasi Manajemen Berbasis Sekolah (MBS) pada hakikatnya adalah pemberian otonomi yang lebih luas kepada sekolah dengan tujuan akhir meningkatkan mutu hasil penyelenggaraan pendidikan, sehingga bisa menghasilkan prestasi yang sebenarnya melalui 
proses manajerial yang mapan. Dalam konteks ini, sekolah memiliki wewenang untuk mengambil keputusan (Gojali \& Umiarso, 2010).

Husni Sabil, 2014 dalam (Mulyasa, 2004) berpendapat bahwa agar MBS dapat berjalan dengan tertib, lancar dan benar-benar terintegrasi dalam suatu sistem kerja sama untuk mencapai tujuan, sedikitnya terdapat 7 (tujuh) komponen yang harus dikelola secara desentralisasi, yaitu kurikulum dan program pengajaran, tenaga kependidikan, kesiswaan, keuangan, sarana dan prasarana pendidikan, hubungan sekolah dan masyarakat, serta manajemen pelayanan khusus lembaga pendidikan.

\section{Pentingnya MBS Bagi Guru dan Siswa}

Pentingnya MBS bagi guru adalah guru memiliki komitmen dan harapan yang tinggi bahwa anak didiknya dapat mencapai tingkat prestasi yang maksimal, walaupun dengan segala keterbatasan sumber daya pendidikan yang ada disekolah. Guru berperan sebagai fasilitator, mediator, pendukung, pemberi pertimbangan, pemberdaya, pembimbing, tutor, dan mentor untuk melayani dan membantu siswa dalam segala persoalan yang dihadapinya di lingkungan sekolah. Sebaliknya MBS berperan penting bagi siswa dalam memberikan motivasi untuk selalu meningkatkan diri berprestasi sesuai dengan bakat dan kemampuannya (Rohiat, 2012).

Dalam rangka mengimplementasikan MBS secara efektif dan efisien, guru harus berkreasi dalam meningkatkan manajemen kelas. Guru adalah teladan dan panutan langsung para siswa di kelas. Oleh karena itu, guru perlu siap dengan segala kewajiban, baik manajemen maupun persiapan isi materi pengajaran.

Dalam melaksanakan MBS, guru harus mengorganisasikan kelasnya dengan baik. Jadwal pelajaran, pembagian tugas peserta didik, kebersihan, keindahan dan ketertiban kelas, pengaturan tempat duduk peserta didik, penempatan alat-alat dan lain-lain harus dilakukan dengan sebaik-baiknya. Suasana kelas yang menyenangkan dan penuh disiplin sangat diperlukan untuk mendorong semangat belajar siswa. Kreativitas dan daya cipta guru untuk mengimplementasikan MBS perlu terus menerus di dorong dan dikembangkan (Mulyasa. 2004).

Sebaliknya yang dilakukan para siswa agar tercapainya tujuan MBS di sekolah adalah harus menunjukkan komitmennya untuk belajar dengan tekun, ulet, cerdas, dan sanggup belajar keras. Para orang tua juga wajib mendorong dan mengingatkan anak-anaknya untuk belajar dengan benar dan baik. Prestasi siswa dapat dimaksimalkan melalui peningkatan partisipasi orang tua, misalnya orang tua dapat mengawasi langsung proses belajar anaknya.

\section{METODOLOGI}

Berdasarkan tujuan penelitiannya penelitian ini adalah penelitian deskriptif karena akan lebih aktual dan cermat untuk melukiskan secara sistematis fakta dan data serta fenomena yang dihadapi, guna menjawab permasalahan yang akan diteliti. Menurut Nanang (2011) penelitian deskriptif bertujuan untuk menggambarkan karakter suatu variabel, kelompok atau gejala sosial yang terjadi di masyarakat.

Untuk teknik pengumpulan data, penelitian ini menggunakan penelitian kuantitatif. Menurut Nanang (2011) penelitian kuantitatif adalah penelitian yang dilakukan dengan mengumpulkan data yang berupa angka. Data yang berupa angka tersebut kemudian diolah dan dianalisis untuk mendapatkan suatu informasi ilmiah di balik angka-angka tersebut.

Penelitian ini menggunakan metode penelitian survei, karena tipe penelitian ini menggunakan kuesioner atau angket sebagai sumber data utama. Dalam penelitian survei, responden diminta untuk memberikan jawaban singkat yang sudah tertulis di dalam kuesioner atau angket kemudian jawaban dari seluruh responden tersebut diolah menggunakan teknik analisis kuantitatif tertentu (Nanang, 2011).

Definisi pemahaman guru dan siswa adalah penguasaan konsep yang diperoleh guru dan siswa yang diketahui melalui pemberian angket tertutup pilihan ganda tentang MBS, dengan pilihan jawaban sangat paham, paham, cukup paham, kurang paham, dan tidak 
paham. Indikator untuk masing-masing subvariabel adalah (1) Manajemen kurikulum dan program pengajaran meliputi: materi, pengujian, perencanaan proses belajar mengajar (PBM), pelaksanaan proses belajar mengajar (PBM), evaluasi proses belajar mengajar (PBM); (2) Manajemen tenaga kependidikan meliputi: perencanaan pegawai, pengadaan pegawai, hubungan kerja, evaluasi kinerja; (3) Manajemen kesiswaan meliputi: penerimaan siswa baru, kegiatan kemajuan belajar, bimbingan dan pembinaan disiplin; (4) Manajemen keuangan dan pembiayaan: perencanaan, penggunaan dana, pertanggungjawaban; (5) Manajemen sarana dan prasarana meliputi: perencanaan, pengadaan, penyimpanan inventarisasi, pemeliharaan dan perbaikan; (6) Manajemen hubungan sekolah dengan masyarakat meliputi: fungsi pokok, tujuan humas, bentuk operasional; (7) Manajemen layanan khusus meliputi: manajemen perpustakaan, kesehatan sekolah, dan keamanan sekolah.

Populasi yang digunakan dalam penelitian ini sebanyak 56 orang guru dan 248 orang siswa di SMP Negeri 8 Palangka Raya. Dalam penelitian ini, instrumen yang digunakan adalah instrumen standar yang dibuat oleh BSNP (Badan Standar Nasional Pendidikan) yang telah teruji kesahihan dan keandalannya sehingga data yang diperoleh diharapkan akan sesuai dengan fakta atau keadaan sesungguhnya di lapangan. Adapun instrumen dalam penelitian ini adalah angket/kuisioner. Angket terdiri dari variabel $(X)$ yaitu pemahaman guru dan siswa, sedangkan variabel $(\mathrm{Y})$ yaitu manajemen berbasis sekolah (MBS). Dengan jumlah butir pernyataan 58 soal angket/kuisioner.

Teknik pengumpulan data yang diperlukan untuk mengumpulkan data dalam penelitian ini adalah:

1. Kuesioner / Angket

Kuesioner / angket yang digunakan untuk memperoleh data dalam penelitian ini adalah jenis angket tertutup, artinya kuesioner diberikan langsung kepada responden kemudian responden tinggal memilih alternatif jawaban yang sudah diberikan yang berisi 5 pilihan jawaban yang terdiri atas pilihan sangat paham, paham, cukup paham, kurang paham, dan tidak paham yang masing-masing mewakili kondisi nyata yang ada di lapangan. Alasan peneliti memilih angket tertutup adalah memudahkan responden untuk mengisinya dan jawaban yang diisi mempunyai patokan / nilai yang jelas.

\section{Wawancara}

Dalam penelitian ini peneliti melakukan wawancara langsung dengan kepala sekolah, wakasek kurikulum, beberapa guru mata pelajaran serta siswa sebagai cross check untuk memperoleh informasi secara langsung dari pihak yang bersangkutan dan hasilnya digunakan untuk melengkapi pembahasan. Wawancara dengan kepala sekolah tentang pelaksanaan manajemen kurikulum, manajemen tenaga kependidikan, dan humas; wakasek kurikulum tentang perencanaan, pelaksanaan, dan evaluasi proses belajar mengajar yang dilakukan oleh guru dalam pelaksanaan MBS; wakasek kesiswaan tentang pelaksanaan manajemen urusan kesiswaan; wakasek sapra tentang pelaksanaan dan pengelolaan sarana dan prasarana sekolah; dan bagian pengelola perpustakaan, uks, serta laboratorium.

3. Dokumentasi

Dalam penelitian ini dokumentasi digunakan untuk mencari data guna melengkapi dan memperkuat data yang diperoleh. Pada penelitian ini dokumen yang digunakan adalah satuan pelajaran, nilai rapor siswa, profil sekolah yang didapatkan dari bagian tata usaha, serta dokumentasi berupa foto-foto kegiatan yang diadakan SMP Negeri 8 Palangka Raya. Satuan pelajaran digunakan untuk mengetahui tema pokok bahasan, sedangkan daftar nilai / rapor untuk mengetahui hasil pengelolaan proses belajar mengajar yang meliputi perencanaan, pelaksanaan, dan evaluasi yang dilaksanakan di SMP Negeri 8 Palangka Raya dan hasilnya digunakan untuk melengkapi pembahasan. Untuk mengetahui tingkat pemahaman guru dan siswa tentang pelaksanaan manajemen berbasis sekolah digunakan analisis deskriptif, artinya seluruh data yang terkumpul diolah untuk menggambarkan situasi hasil penelitian.

Data yang diperoleh dari hasil angket dan disusun dalam bentuk tabel (tabulasi data) yang selanjutnya di analisis dengan menggunakan perhitungan persentase deskripsi rumus adalah: 
$P=\frac{\mathbf{n}}{\mathbf{N}} X 100 \%$

Keterangan:

$\mathrm{P}=$ Persentase skor yang diperoleh untuk setiap indikator

$\mathrm{N}$ = Skor yang diperoleh untuk setiap indikator

$\mathrm{N}=$ Skor maksimal

Dari hasil perhitungan dengan rumus di atas kemudian disesuaikan dengan tabel deskriptif persentase yang dikelompokkan menjadi 5 kategori dengan tingkat persentase tertinggi $100 \%$ dan terendah $20 \%$ yaitu:

Tabel 1.

Deskriptif Persentase

\begin{tabular}{|c|c|c|}
\hline No. & Persentase (\%) & Keterangan \\
\hline 1. & $85-100$ & Baik Sekali \\
\hline 2. & $70-84$ & Baik \\
\hline 3. & $55-69$ & Cukup \\
\hline 4. & $40-54$ & Kurang \\
\hline 5. & $<39$ & Kurang Sekali \\
\hline
\end{tabular}

\section{HASIL DAN PEMBAHASAN}

Dalam mengawali penyajian data ini kegiatan yang dilakukan adalah menyebarkan angket kepada para responden yang terdiri dari guru tetap sebanyak 56 orang, siswa kelas VII sebanyak 124 orang, serta siswa kelas VIII sebanyak 124 orang. Cara yang dilakukan adalah dengan pengambilan secara acak dari sejumlah populasi yang ditetapkan sebelumnya.

Adapun hasil analisis nilai rata-rata secara keseluruhan angket yang peneliti sebarkan kepada para guru tentang pemahaman MBS di SMP Negeri 8 Palangka Raya sebagai berikut:

Tabel 2.

\section{Hasil Persentase Keseluruhan Pemahaman Guru Tentang Manajemen Berbasis Sekolah}

\begin{tabular}{|c|l|c|c|}
\hline No. & \multicolumn{1}{|c|}{ Indikator } & Persentase & Keterangan \\
\hline 1. & Manajemen Kurikulum dan Program Pengajaran. & $77,62 \%$ & Baik \\
\hline 2. & Manajemen Tenaga Kependidikan. & $61,60 \%$ & Cukup \\
\hline 3. & Manajemen Kesiswaan. & $70,09 \%$ & Baik \\
\hline 4. & Manajemen Keuangan dan Pembiayaan. & $72,32 \%$ & Baik \\
\hline 5. & Manajemen Sarana dan Prasarana. & $65,63 \%$ & Cukup \\
\hline 6. & $\begin{array}{l}\text { Manajemen Hubungan Sekolah dengan } \\
\text { Masyarakat. }\end{array}$ & $77,98 \%$ & Baik \\
\hline 7. & Manajemen Layanan Khusus. & $76,19 \%$ & Baik \\
\hline \multicolumn{2}{|c|}{ Rata-Rata } & $71,63 \%$ & BAlK \\
\hline
\end{tabular}

Selanjutnya hasil analisis perhitungan dari angket yang telah peneliti sebarkan kepada para siswa untuk mengetahui persentase pemahaman siswa tentang MBS di SMP Negeri 8 Palangka Raya sebagai berikut: 
Tabel 3.

Hasil Persentase Keseluruhan Pemahaman Siswa Tentang Manajemen Berbasis Sekolah

\begin{tabular}{|c|l|c|c|}
\hline No. & \multicolumn{1}{|c|}{ Indikator } & Persentase & Keterangan \\
\hline 1. & Manajemen Kurikulum dan Program Pengajaran. & $55,51 \%$ & Cukup \\
\hline 2. & Manajemen Tenaga Kependidikan. & $65,32 \%$ & Cukup \\
\hline 3. & Manajemen Kesiswaan. & $58,74 \%$ & Cukup \\
\hline 4. & Manajemen Keuangan dan Pembiayaan. & $62,90 \%$ & Cukup \\
\hline 5. & Manajemen Sarana dan Prasarana. & $64,78 \%$ & Cukup \\
\hline 6. & $\begin{array}{l}\text { Manajemen Hubungan Sekolah dengan } \\
\text { Masyarakat. }\end{array}$ & $55,37 \%$ & Cukup \\
\hline 7. & Manajemen Layanan Khusus. & $56,45 \%$ & Cukup \\
\hline \multicolumn{2}{|c|}{ Rata-Rata } & $59,87 \%$ & CUKUP \\
\hline
\end{tabular}

Berdasarkan hasil perhitungan analisis angket (kuisioner) yang telah dilakukan, untuk mempermudah penjelasan dan melihat perbedaan tingkat pemahaman guru dan siswa tentang MBS maka dibuatlah diagram sebagai berikut:

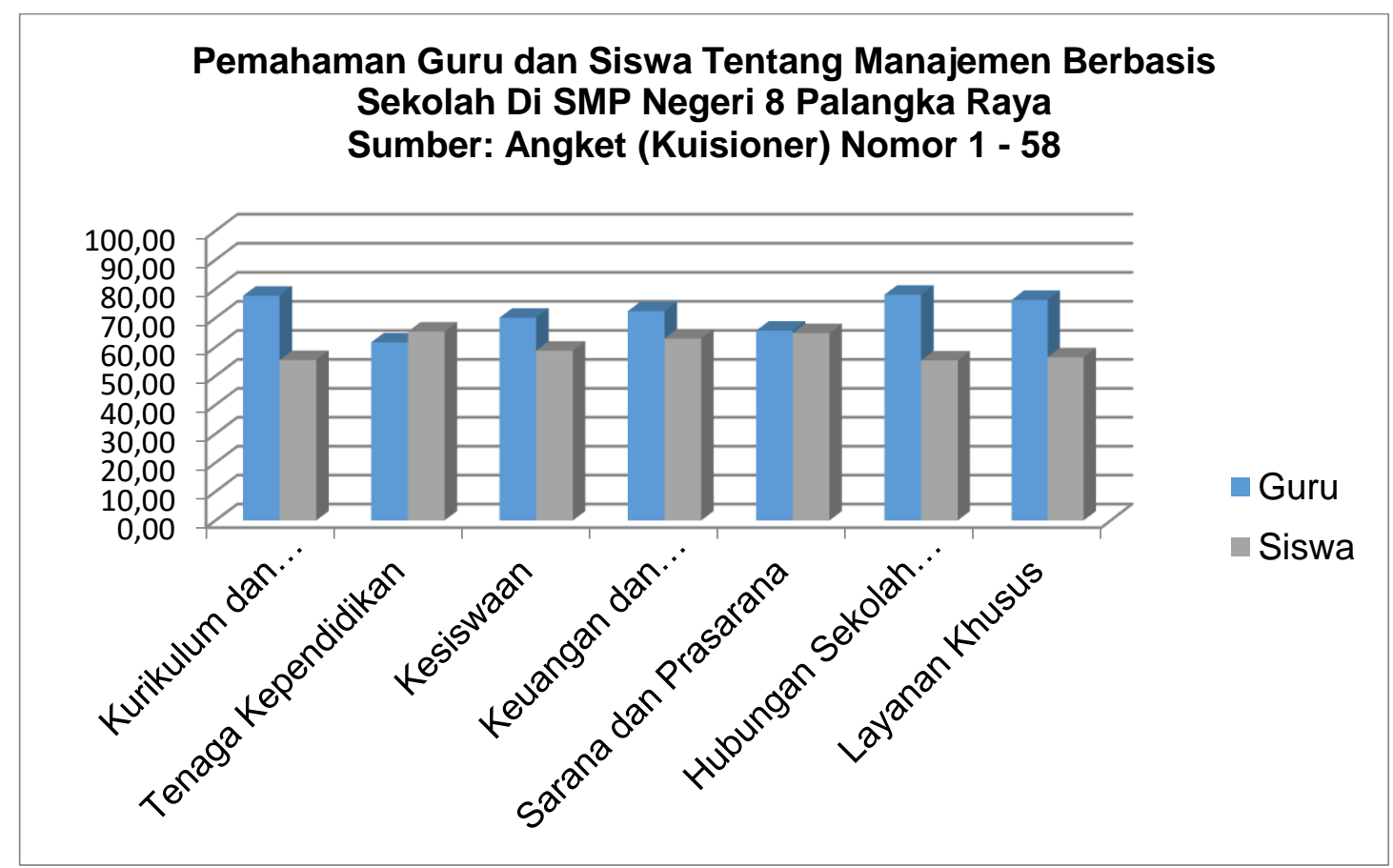

Gambar 1.

Grafik Tingkat Pemahaman Guru dan Siswa Tentang Manajemen Berbasis Sekolah

Dari grafik di atas, terlihat bahwa pemahaman guru tentang MBS memiliki rata-rata yang lebih baik dibandingkan pemahaman siswa. Menurut hasil analisis data, sebagaimana disajikan dalam bentuk persentase dari masing-masing sub variabel yaitu manajemen kurikulum dan program pengajaran, manajemen tenaga kependidikan, manajemen kesiswaan, manajemen keuangan dan pembiayaan, manajemen sarana dan prasarana, manajemen hubungan sekolah dengan masyarakat, serta manajemen layanan khusus menunjukan hasil secara berturut-turut yaitu 71,63 \% dan 59,87\%. Berdasarkan tabel kriteria persentase yang telah ditentukan, persentase tersebut menunjukkan bahwa pemahaman 
guru dan siswa tentang Manajemen Berbasis Sekolah di SMP Negeri 8 Palangka Raya termasuk dalam kategori BAIK dan CUKUP.

Hal ini tidak terlepas dari peran kepala sekolah yang sangat sentral dalam membuat dan melaksanakan MBS, penentu kebijakan utama yang ada di setiap satuan pendidikan. Selain itu kepala sekolah sebagai pemimpin yang menggunakan wewenang formalnya untuk mengorganisasi, mengarahkan, dan mengontrol para bawahannya agar bertanggung jawab terhadap pekerjaannya, supaya semua bagian pekerjaan dikoordinasi demi sesuai dengan visi misi sekolah yang telah dibuat. Pengawasan dilakukan oleh Komite Sekolah dan Dinas Pendidikan Kota Palangka Raya, dalam hal ini Pengawas SMP secara periodik dan berkesinambungan agar pelaksanaan MBS di SMP Negeri 8 Palangka Raya benar-benar terpantau dan berjalan sesuai rambu-rambu yang ada.

Indikator yang menunjukkan karakter dari konsep manajemen berbasis sekolah di SMP Negeri 8 Palangka Raya antara lain: (1) lingkungan sekolah yang aman dan tertib; (2) sekolah memiliki misi dan target mutu yang ingin dicapai; (3) sekolah memiliki kepemimpinan yang kuat; (4) adanya harapan yang tinggi dari personil sekolah (kepala sekolah, guru, dan staf lainnya termasuk siswa) untuk berprestasi; (5) adanya pengembangan staf sekolah yang terus menerus sesuai tuntutan IPTEK; (6) adanya pelaksanaan evaluasi yang terus menerus terhadap berbagai aspek akademik dan administratif; serta (7) adanya komunikasi dan dukungan intensif dari orang tua siswa / masyarakat.

Berdasarkan pembahasan di atas, didapatkan hasil penelitian yang menunjukkan bahwa guru mampu menyesuaikan antara konsep manajemen berbasis sekolah dengan materi/pokok pelajaran, sehingga dengan adanya pelaksanaan proses belajar mengajar yang meliputi perencanaan, pelaksanaan, dan evaluasi yang baik juga mempengaruhi dan mendapatkan hasil yang memuaskan. Dengan kata lain, pelaksanaan manajemen berbasis sekolah dengan kualitas yang tinggi akan berpengaruh terhadap peningkatan belajar siswa.

Hasil penelitian ini juga menunjukkan bahwa pemahaman para guru mengenai manajemen berbasis sekolah tergolong baik dan pemahaman siswa masih dalam kategori cukup. Hal ini dikarenakan kurangnya sosialisasi, pelatihan, maupun seminar yang dilakukan oleh Dinas Pendidikan terkait dengan Manajemen Berbasis Sekolah.

\section{PENUTUP}

Berdasarkan hasil penelitian dan pembahasan analisis data yang telah diuraikan dapat ditarik kesimpulan bahwa guru dan siswa di SMP Negeri 8 Palangka Raya telah memahami tentang Manajemen Berbasis Sekolah yang terbukti dengan hasil jawaban dari angket / kuisioner. Pemahaman guru berada dalam kategori BAIK dengan hasil persentase $71,63 \%$ dan pemahaman siswa berada dalam kategori CUKUP dengan hasil persentase $59.87 \%$.

Dari data di atas dapat diuraikan hasil persentasenya sebagai berikut:

1. Pemahaman guru dan siswa tentang manajemen kurikulum dan program pengajaran masing-masing berada dalam kategori baik (77,62 \%) dan cukup (55,51\%). Pemahaman responden bahwa perlu adanya perencanaan proses belajar mengajar (PBM) yang meliputi adanya rencana pembelajaran tahunan, rencana pembelajaran semester, rencana pembelajaran mingguan, dan rencana pembelajaran harian. Pelaksanaan proses belajar mengajar (PBM) dengan memanfaatkan sumber belajar yang tersedia. Evaluasi proses belajar mengajar (PBM) dilakukan sebelum, selama, dan sesudah kegiatan belajar mengajar berlangsung.

2. Pemahaman guru dan siswa tentang manajemen tenaga kependidikan masingmasing berada dalam kategori cukup baik yaitu $61,60 \%$ dan $65,32 \%$, ini berarti pimpinan harus lebih meningkatkan pengelolaan tenaga kependidikan yang tersedia di sekolah.

3. Pemahaman guru dan siswa tentang manajemen kesiswaan termasuk dalam kategori baik dan cukup baik, hal ini sesuai dengan persentase 70,09 \% untuk pemahaman guru dan 58,74 \% untuk pemahaman siswa. Sekolah tidak hanya bertanggungjawab memberikan berbagai ilmu pengetahuan, tetapi memberikan bimbingan dan mendidik mental para siswa yang bermasalah, baik dalam belajar, 
emosional, maupun sosial sehingga dapat tumbuh dan berkembang secara optimal sesuai dengan potensi masing-masing serta mempunyai karakter yang terpelajar.

4. Pemahaman para guru terhadap manajemen keuangan dan pembiayaan tergolong baik dengan persentase $72,32 \%$. Sebaliknya pemahaman siswa terhadap manajemen keuangan dan pembiayaan menunjukkan persentase $62,90 \%$ dengan hasil kategori cukup. Hal ini membuktikan kemampuan sekolah untuk merencanakan, melaksanakan, mengevaluasi, serta mampu mempertanggungjawabkan pengelolaan dana secara transparan dan akuntabel kepada masyarakat dan pemerintah.

5. Pemahaman guru dan siswa mengenai manajemen sarana dan prasarana masih tergolong cukup dengan masing-masing menunjukkan persentase $65,63 \%$ dan $64,78 \%$. Ini berarti sekolah perlu menciptakan sekolah yang bersih, rapi, indah sehingga menciptakan kondisi yang menyenangkan baik bagi guru maupun siswa untuk berada di sekolah.

6. Pemahaman guru mengenai manajemen hubungan sekolah dengan masyarakat tergolong baik dengan persentase $77,98 \%$. Sedangkan pemahaman siswa mengenai manajemen hubungan sekolah dengan masyarakat masih tergolong cukup dengan persentase $55,37 \%$. Hal ini berarti sekolah dan masyarakat memiliki hubungan yang sangat erat dalam mencapai tujuan sekolah atau pendidikan secara efektif dan efisien. Rasa tanggungjawab dan partisipasi warga sekolah (guru, pegawai, siswa) serta masyarakat (orang tua siswa) untuk memajukan sekolah sangat tinggi. Dibutuhkan komitmen yang kuat untuk bersama mewujudkan dengan baik visi dan misi sekolah.

7. Pemahaman guru mengenai manajemen layanan khusus menunjukkan persentase $76,19 \%$ dengan kategori baik, sedangkan pemahaman siswa menunjukkan kategori cukup dengan persentase 56,45 \%. Hal ini berarti bahwa sekolah tidak hanya bertugas mengembangkan ilmu pengetahuan, keterampilan dan sikap, tetapi juga menjaga dan meningkatkan kesehatan jasmani dan rohani siswa.

8. Dalam pelaksanaannya, pemahaman para guru masih ada kekurangan-kekurangan yang harus di evaluasi lagi terutama pada manajemen tenaga kependidikan, sarana dan prasarana. Sedangkan para siswa rata-rata masih belum memahami pengertian manajemen berbasis sekolah tersebut. Hal ini mengindikasikan bahwa sekolah perlu bekerjasama dengan pihak-pihak yang terkait dalam dunia pendidikan untuk lebih mensosialisasikan mengenai manajemen berbasis sekolah, karena selama ini masih jarang bahkan belum pernah dilakukan seminar melibatkan guru-guru bahkan siswa untuk lebih mengenal mengenai manajemen berbasis sekolah. SMP Negeri 8 Palangka Raya sudah melaksanakan manajemen berbasis sekolah secara efektif dan efisien dengan didukung oleh sumber daya manusia yang profesional untuk mengoperasikan sekolah, dana yang cukup dimiliki sekolah untuk menggaji staf sesuai dengan fungsinya, sarana dan prasarana yang memadai dan mampu menunjang proses belajar mengajar, serta dukungan masyarakat (orang tua siswa) yang tinggi.

Berdasarkan hasil penelitian dari kesimpulan yang telah dikemukakan di atas ada beberapa saran kepada berbagai pihak terkait penelitian ini yaitu sebagai berikut:

1. Secara teoritis, saran yang dapat penulis berikan bagi SMP Negeri 8 Palangka Raya adalah agar lebih berupaya untuk meningkatkan pemahaman dan mengembangkan kualitas sumber daya manusia (guru, pegawai tata usaha, siswa) melalui pendidikan, pelatihan, maupun seminar pendidikan tentang manajemen berbasis sekolah.

2. Secara praktis, saran yang dapat penulis berikan bagi Kepala Sekolah adalah agar lebih memanfaatkan potensi, kekuatan, peluang, kelemahan, serta tantangan yang ada di dalam sekolah sebagai dasar bertindak dalam menyusun program dan mengatasi masalah yang ada di lingkungan sekolah. Lebih memahami secara mendasar hakekat dan implementasi MBS di sekolahnya, mampu menjelaskan kepada warga sekolah dan stakeholder lainnya, serta menjamin keberlangsungan 
MBS di sekolahnya secara mandiri dan berkelanjutan. Selanjutnya bagi Guru, disarankan mampu mengevaluasi kinerja diri (self-assesment), mengidentifikasi kelemahan dan permasalahan serta menindaklanjuti dalam program manajemen berbasis sekolah (selalu ada perbaikan diri). Sedangkan saran bagi Siswa, agar tercapainya tujuan manajemen berbasis sekolah di SMP Negeri 8 Palangka Raya adalah harus menunjukkan komitmennya untuk belajar dengan tekun, ulet, cerdas, dan sanggup belajar keras, agar diperoleh siswa yang siap belajar dan memiliki karakter terpelajar.

Manfaat yang diperoleh jika guru dan siswa memahami tentang MBS maka akan lahir orang-orang yang berkompeten di sekolah untuk mengambil keputusan yang akan meningkatkan pembelajaran; memberi peluang bagi seluruh guru untuk terlibat dalam pengambilan keputusan penting; meningkatkan motivasi guru dan mengembangkan jiwa kepemimpinan; guru memiliki kematangan sosial maupun emosional dalam berinteraksi dengan siswa dan anggota sekolah lainnya; diperolehnya siswa yang siap belajar; siswa yang memiliki grade yang cukup, bahkan lebih dari cukup; siswa aktif mengikuti kegiatan di sekolah; prestasi akademik maupun ekstrakurikulernya baik, tidak bolos, tidak tinggal kelas, dan tidak drop out.

\section{DAFTAR PUSTAKA}

Asmani, Jamal Ma'mur. (2012). Tips Aplikasi Manajemen Sekolah. Yogyakarta: DIVA Press. Depdiknas. (2009). Manajemen Berbasis Sekolah dalam Kerangka Pemenuhan. Standar Nasional Pendidikan. Jakarta: Direktorat Mandikdasmen.

Dolong, J. (2018). Karakteristik Manajemen Pendidikan Berbasis Sekolah. Inspiratif Pendidikan, 7 (1), 1-10.

Gojali, Imam \& Umiarso. (2010). Manajemen Mutu Sekolah di Era Otonomi Pendidikan. Jogjakarta: IRCiSoD.

Ismail, F. (2018). Manajemen Berbasis Sekolah: Solusi Peningkatan Kualitas Pendidikan. Jurnal IImiah lqra' Institut Agama Islam Negeri Manado, 2 (2).

Martono, Nanang. (2011). Metode Penelitian Kuantitatif; Analisis Isi dan Analisis Data Sekunder. Jakarta: Raja Grafindo Persada.

Mulyasa. (2007). Menjadi Kepala Sekolah Profesional. Bandung: PT. Remaja Rosdakarya.

--------. (2004). Manajemen Berbasis Sekolah (Konsep, Strategi dan Implementasi), Bandung: PT. Remaja Rosdakarya.

Rohiat. (2012). Manajemen Sekolah; Teori Dasar dan Praktik. Bandung: PT. Refika Aditama.

Sabil, H. (2014). Implementasi Manajemen Berbasis Sekolah (MBS) di SMPN 11 Kota Jambi. Sainmatika: Jurnal Sains dan Matematika Universitas Jambi, 8 (1), 221069.

Sutarto, M., Darmansyah, D., \& Warsono, S. (2014). Manajemen Berbasis Sekolah. The Manager Review Jurnal Ilmiah Manajemen Universitas Bengkulu, 13 (3), 343-355.

Triwiyanto, T. (2013). Pemetaan Mutu Manajemen Berbasis Sekolah Melalui Audit Manajemen Pendidikan. Jurnal Manajemen Pendidikan Universitas Negeri Malang, 24 (2), 125-135.

Undang-Undang Republik Indonesia Nomor 20 Tahun 2003 tentang Sistem Pendidikan Nasional.

Usman, Husaini. (2008). Manajemen; Teori, Praktik, dan Riset Pendidikan. Jakarta: PT. Bumi Aksara. 